\title{
Formation of Production Areas in the Japanese Broiler Chicken Industry
}

\author{
Masanobu NAGASAKA*
}

\begin{abstract}
In this study, the regional conditions for the formation of areas in the broiler chicken industry have been elucidated through an examination of the area formation processes. Furthermore, the general conditions in production area formation have been investigated.

As for study areas, four areas were selected: the Tajima area in Hyogo and Fuji area in Shizuoka were chosen as the production areas located in the environs of metropolitan regions. While the Koyu area in Miyazaki and the northern area of Iwate were selected as case studies in the periphery.

General conditions found in the study for the formation of production area in the broiler chicken industry are as follows.

The first is the participation of business firms and agricultural cooperatives' groups as an integrator in the industry, setting up processing factories through which they developed competition to secure broiler chicken raising farms. Consequently, expanding the production area spatially, the farms gradually enlarged their sizes to carry out specialized management.

The second is the predominance of marginal farms on the less favored areas where the integrators moved. These marginal farms which did not have much alternative were willing to raise broiler chickens, expecting larger incomes and stable farm management.

The third is the special attributes of the broiler chicken industry such as a relatively small initial investment, and the simplicity of chicken raising which enables easy participation for even an unexperienced farm household, and an assurance of relatively high income.
\end{abstract}

Key words: broiler industry, production area formation, Tajima area, Fuji area, Koyu area, Northern area of Iwate.

\section{INTRODUCTION}

\section{Purpose}

The broiler chicken industry of Japan, a fairly recently livestock industry which began its full-swing operation in the 1960's, has achieved the most rapid and remarkable development in the agricultural history of Japan.

The integrated system of the livestock industry as it emerged from the broiler chicken raising section in the 1960's, was promoted by business firms, their subsidiary feed firms and the meat processing firms. This situation came from a heavy dependence of the livestock industry on imported feed. A large portion of the feed and the chicks were imported. Taking advantage of their import business, business firms started incorporating broiler chicken enterprises from production and processing to distribution in order to expand their range of profit.

There has emerged a certain spatial pattern as the integration developed, because the units of the broiler chicken industry, i.e. chicken farms, hatcheries, processing factories and feed plants, formed a regional production group. In addition, the regional development of the broiler chicken industry proceeded in the following manner: The production regions were expanded gradually from the environs of the metropolitan regions to the rural areas, in which the main production areas came to be formed in

\footnotetext{
* Department of Teacher Education, Kinki University, Kowakae, Higashi-Osaka-shi, Osaka 577, Japan.
} 
the 1970's. But only a limited number of research studies on the production area formation in the broiler chicken industry have so far been made.

This study first investigates the process of the production area formation, and then clarifies its regional conditions. Thus, the discussion is made on the general conditions for the formation of production areas in the broiler chicken industry.

\section{Previous studies and problems}

Midoro et al. (1963), Takenaka (1963), and Usui and Yoshida (1965) discuss the formation of the production area by placing their emphasis on the structure of the production. But they show little concern about the methods used by business and agricultural integrators to induce farm households to raise broiler chickens.

Nagashima (1969) and Kitamura (1986a, $1986 \mathrm{~b}$ and 1987) published reports on the geographical study of the poultry raising industry. Nagashima points out three management types in Japan, i.e. specialized, enterprise, and cooperatives or group types. Further, he makes clear the regional characteristics in the distribution of these types. While this study take notice of the regional differences in the size of the poultry farms, it examines neither integration by the non-agricultural firms nor the types of management practiced by farm households.

Kitamura first discussed the regional formation of poultry in Takahama City, one of the main poultry raising areas in Aichi Prefecture, and brought up the subjects of management conducted by the farm households and of poultry raising. Employing cluster analysis, he identified factors that brought about the regional formation of poultry raising in Aichi. Through the series of research projects, he attempted to identify the general conditions contributing to the formation of the poultry raising region and explain the phenomena systematically.

The author of this study has been undertaking a series of studies on the production area in the broiler chicken industry $(1983,1988$ and 1989). First, he analyzed the production area formation through examining the integration process of broiler chicken farms by the processing factory in Miyazaki Prefecture. He did a similar study in northern Iwate where the development of the integration system in the broiler chicken industry was most remarkable. $\mathrm{He}$ analyzed the requirements for the production area formation in the broiler chicken industry in the Tajima area, too.

In the studies on the production area of poultry raising, little consideration has been given to physical characteristics. Further, no clear-cut definition of the production area has been made.

\section{Methods}

The process of the formation of production area may be influenced by the structure of the market as well production in the region. The research by Midoro et al. (1963) treated the poultry production area formation in relation to the transformation of market structure. In order to study the present-day regional structure of the broiler chicken industry, the integration system should be analyzed from both sides of the integrator and the integrated, and the characteristics of the production group in relation to the locality and density of the farms.

To be comprehensive, the study must cover the following stages: (1) construction of the regional model; (2) selection of suitable study areas based on this model; and (3) investigation and analysis of the selected regions.

According to this procedure, an analysis will be made in the first place on the regional development of the broiler chicken industry from the three aspects of the industry, i.e. production, processing and distribution. In the next step, the core areas of the industry will be examined based on the result of the analysis. For this purpose, a production area is defined here as the region that satisfies two requirements, i.e. (1) the broiler chicken raising sector holds high positions in the total agricultural production (gross broiler chicken production has been ranked above 20 th in the whole country), and (2) the broiler chicken sector holds defined numbers of chickens and related farm households (having been ranked above 20th in the whole country).

The regions are classified into two types, i.e. 
the production area in environs of a metropolitan region and that in the rural area. ${ }^{1)}$ Two types of production areas are further divided into four types with different climatic conditions, and four areas are singled out as the study regions. The regional structure of these four areas are analyzed in terms of the development of this industry. Actual analysis of the broiler chicken industry will be done in the production area in terms of: (1) the activities of the integrators of the processing factory as the center, and (2) the movements of the affiliated farm households.

In Addition, a term "broiler chicken collection region ${ }^{2)}$ is used here to indicate the territory through which broiler chickens are introduced and live birds are shipped. By use of this term, the production area of the broiler chicken industry will be understood as a functional region where the processing factory and its affiliated farms hold a definite cooperative space. Following the analysis of the actual structure of the production area, the regional characters of the industry will be derived from four core areas in the production areas, and the regional conditions for formation and existence of the production area will be identified.

Finally, three factors for the production area formation in the industry, i.e. the function of the integrator, the management and the location of the respective farms, and the regional structure of the integrated system, will be examined to disclose regionality of the broiler chicken industry. In this connection, the regional conditions of the production area formation will be elucidated through extraction of the common conditions from the study areas.

\section{Selection of study areas}

The investigation of the process of the regional development in the broiler chicken industry of Japan has disclosed that the formation of the production area can be observed in the environs of metropolitan regions, in rural areas and in the intermediate districts (Table 1). The production areas with the smallest number of broiler chicken raising farms are scattered in the environs of the metropolitan regions. Only two production areas exist in the intermediate areas. On the contrary, the rural production areas are concentrated in three prefectures, i.e. Iwate, Miyazaki and Kagoshima. One may observe that these three prefectures form the main production areas of the broiler chicken industry in Japan (Fig. 1).

In determining the production areas to be studied, the selection of two types with different formation periods is appropriate. After this division, the following conditions should be satisfied in selecting regions: (1) locations with different climatic environments, (2) even distribution of the broiler chicken raising farms, (3) farms distributed in a limited area and (4) continuation of a production area for a certain period.

Thus, as the case of the advanced production areas, i.e. the area in the environs of a metropolitan region, two areas, one from western and the other from eastern Japan, were chosen respectively. They are the Tajima area in Hyogo and the Fuji area in Shizuoka, because abovementioned conditions were satisfied in these areas. The broiler chicken industry in Tajima, the oldest in western Japan, has a high standing in the agricultural economy of the area up to the present. In the latter, the development of this industry has been promoted since an early period, particularly in Fujinomiya City, and it holds the largest number of broiler chicken shipment yearly in eastern Japan.

Among the newly emerged production areas located in the rural areas, Iwate and southern Kyushu were selected first. From the former, the northern area of Iwate where the highest broiler chicken farm density was found in the prefecture was selected. From the latter, the Koyu area of Miyazaki with the highest density of the broiler chicken farms was chosen (Fig. 2).

\section{REGIONAL CONDITIONS FOR THE PRODUCTION AREA FORMATION IN BROILER CHICKEN INDUSTRY}

In this section, a comparison of these production areas will be made in order to identify the regional characteristics inherent in the broiler chicken industry.

\section{Function of the broiler integrator}

At the beginning of the 1960's, 11 business 


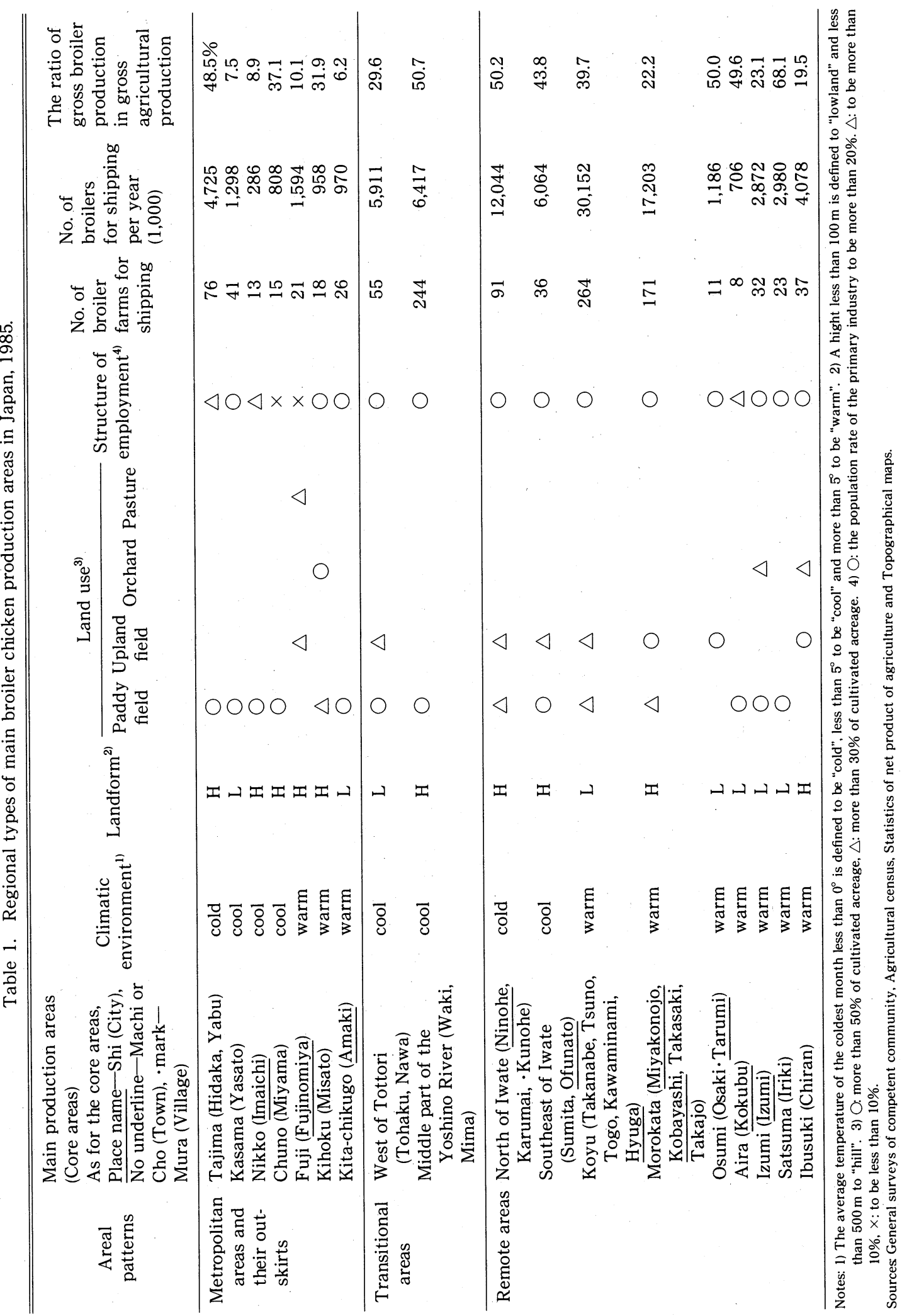




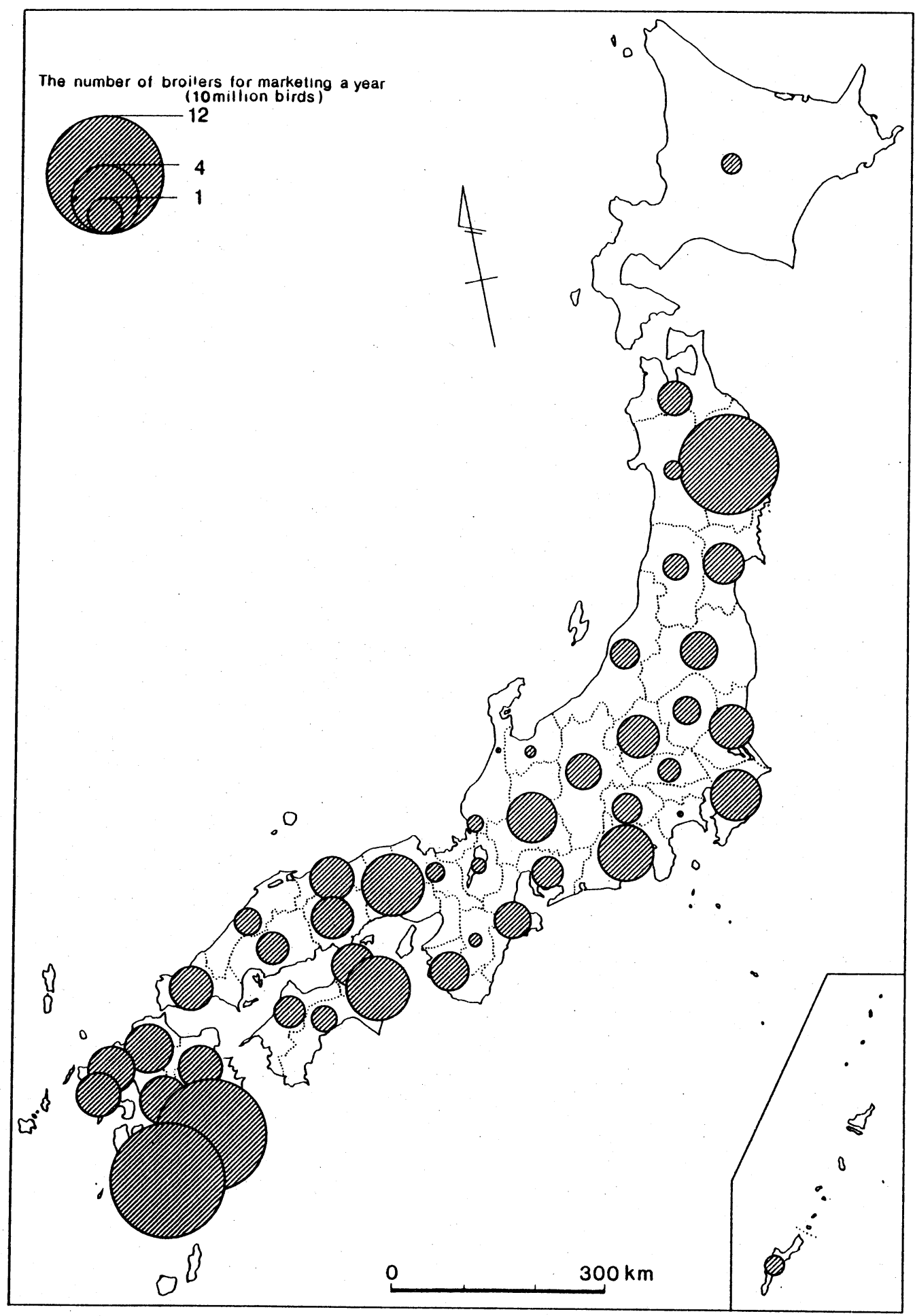

Figure 1. Distribution of the number of broilers for marketing by prefectures, 1985 Data source: Census of livestock products. 


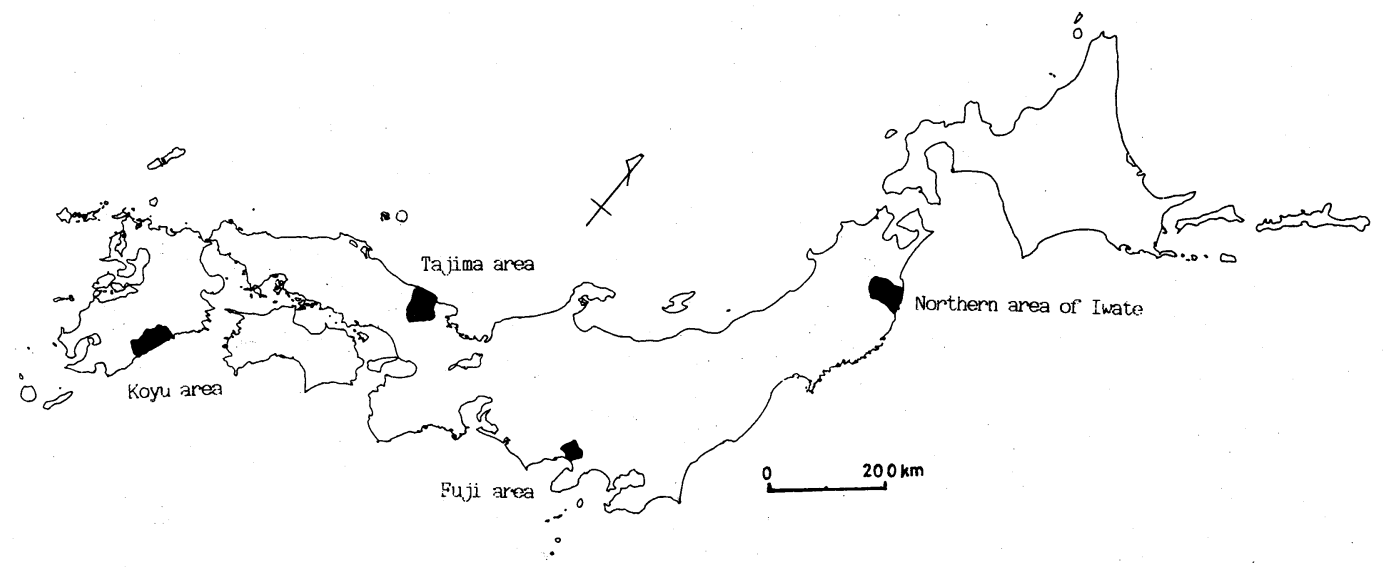

Figure 2. Study areas

firms ${ }^{3)}$ intended to advance directly into the livestock industry to expand their profit ranges in addition to their own trade areas (import of feed and its domestic sale). They established control over production, processing and distribution, and succeeded in organization of the integrated system appropriate for pursuing larger profits. The strategy is that business firms owned the feed plant as a subsidiary or an affiliated company, through which they distributed agencies and special agencies to sell feed. Then, local feed dealers set up the processing factories, and the business firms themselves proceeded into the rural areas to carry out direct production. Moreover, they incorporated meat wholesalers into their groups to distribute the processed broiler chickens to the distributing centers and the supermarkets. They, further, assisted some of the affiliated distributors in setting up processing factories.

However, after the first oil crisis, serious situations were generated, including the price hike in imported feed and the problem of pollution caused by livestock raising, thus deteriorating the market environment. Consequently, the number of farms decreased significantly, jeopardizing the feed dealers' market and forcing some business firms to withdraw altogether from the livestock industry. Four business firms, (Mitsui, Mitsubishi, C. Itoh, and Marubeni) survived those difficulties, and are influential in the present broiler chicken industry.

The agricultural cooperatives, fell behind in entering the broiler chicken industry, but are now attempting to strengthen their organizational relationship with Prefectural Federation of Agricultural Cooperative Associations and with the National Federation of Agricultural Cooperative Associations as their head. They have also attempted to form connections with business firms in the distribution field to cover their weakest point, resulting in a double-sales system. Besides, some farmers, setting up processing factories by themselves, advanced into the wholesale business, and began to carry out company management.

The comparative study on how the processing factory functioned or played its role to develop the broiler chicken industry in each of the four production areas revealed that the patterns of the formation of the production areas could be classified into six types: (1) a business firm leading type-an integrating form in which the business firm conducts the direct management from production through marketing; (2) a local integrator leading type-a form in which a big processing factory holds control over all sectors except feed manufacturing; (3) a local wholesaler leading type-a form in which the local trader affiliated either with a business firm or its incorporated company, such as a feed dealer or meat wholesaler, plans the central role in integration; (4) agricultural cooperative groups leading type-an integrating form in which the management is carried out jointly by National Federation of Agricultural Cooperative Associations, Prefec- 
tural Federation of Agricultural Cooperative Associations and agricultural cooperatives; (5) an agricultural cooperative leading type-a form in which an agricultural cooperative functions as the main integrator, partly depending on the enterprise incorporated by the company; and (6) an agricultural cooperative and a business firm cooperating type-a segmented form in which the agricultural cooperative takes responsibility for production and processing, while a business firm takes charge of distribution.

The Tajima area may be characterized by (2) and (5) for the following reasons. The local feed dealer affiliated with the business firm also conducted wholesale trading to lead the broiler chicken industry of this area. And competition between the said dealer and the late-started agricultural cooperative brought this industry to develop in the Tajima area (Table 2).

In the Fuji area, the agricultural cooperative and the feed dealers withdrew from the broiler business, and the receipt agent, incorporated with the capital of an urban merchant, and the retail store came to be united. As a result, a sole processing factory has remained in this area. Hence, this factory represents type (3) (Table 3).

Miyazaki Prefecture may be characterized by three types, (1), (2) and (4). This is because the formation of the production area was led by business firms. It is also because the broiler chicken industry took root in the district by virtue of competition among the business firm, and the coexisting late-started Prefectural Federation of Agricultural Cooperative Associations and farmer capital (Table 4).

In Iwate Prefecture, the local integrators took leadership in the formation of the production area first, which National Federation of Agricultural Cooperative Associations and agricultural cooperatives joined in the next. Thus, the manifold integration systems, e.g. a joint venture of an agricultural cooperative-affiliated company and a business firm-incorporated firm, have been developed in the course of the production area formation. Hence, Iwate Prefecture can be described by (2), (5) and (6) (Table 5).

A survey on the broiler collection region shows in both the Tajima and the northern area of Iwate that the territories converge in areas ranging from 30 to $40 \mathrm{~km}$. On the contrary, the territories in both Koyu and Fuji areas are expanded to ranges of 70 to $80 \mathrm{~km}$, because a part of the affiliated farms are scattered over peripheral areas outside the prefectures.

In the Koyu area, having been overcrowded with broiler chicken farms, the processing factories of the integrators actively solicited new participants in areas outside the prefecture to meet their increasing processing capacity. In the case of the Fuji area, the broiler chicken raising farms had to be recruited from rural areas, because the number of farms in this area was so limited. To conclude, in the first place, it is commonly observed that the affiliated farms concentrate in the vicinity of the processing factory. Secondly, the production area in a rural area has a higher raising density of chicks than the advanced production area. This may lead to a conclusion that the broadness of the broiler chicken collection region does not necessarily hold any correlation with the degree of the production area development in the broiler chicken industry.

The contract production has been a mainstream method in the broiler chicken industry. The broiler chicken farm offers the broiler chicken shed and labor force, purchases the chicks and the feed from the processing factory, and sells the live birds. The purchase price has been determined by means of the mode of transaction ${ }^{4}$, including the flat-fee-a-year system, the guaranteed payment system and the market price method. Besides, two other production systems can be observed as shown below. In the case of the committed production system, the processing factory sets up the broiler chicken site with the farm household offering land and labor in exchange for financial payment. The other case is the direct production system, in which the members of the farm household are employed under a salary system as workers of a direct farm owned by the processing factory.

In the selected areas, except Fuji, the processing factory adopted the flat-fee-a-year system which particularly included terms of a guaranteed income, the most advantageous for the farm household in order to secure chicken farmers. This system enhanced the farmer's mo- 


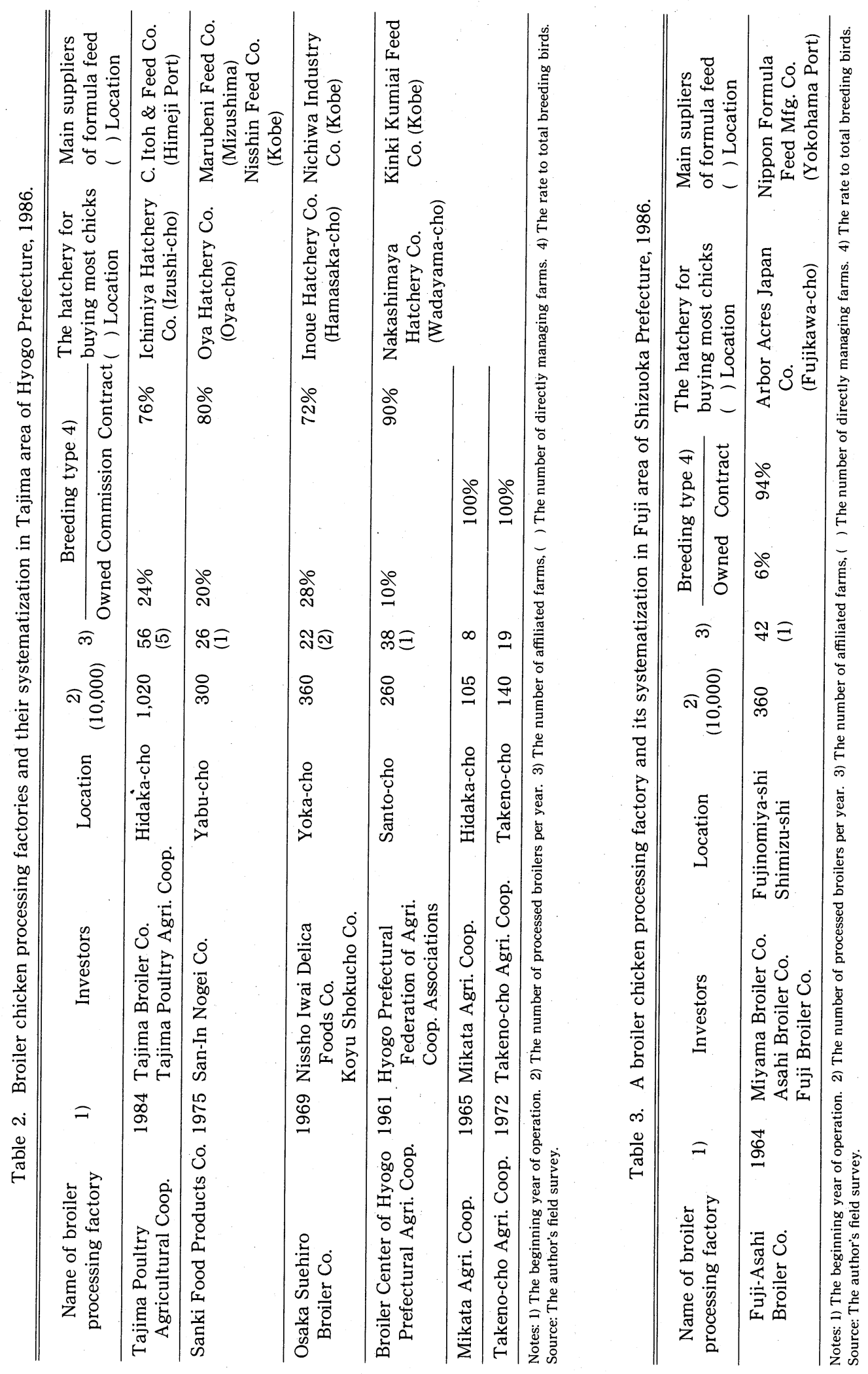




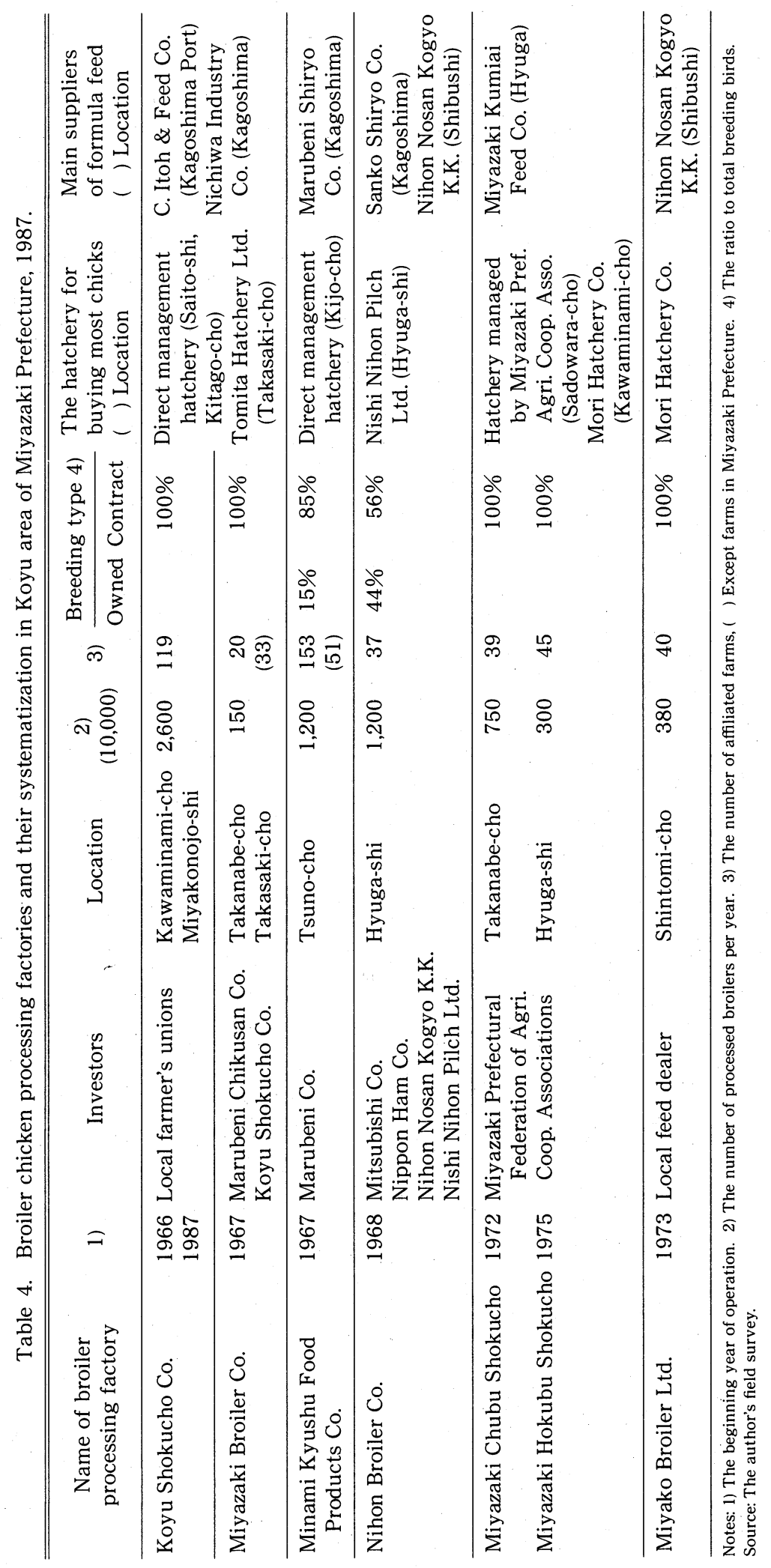




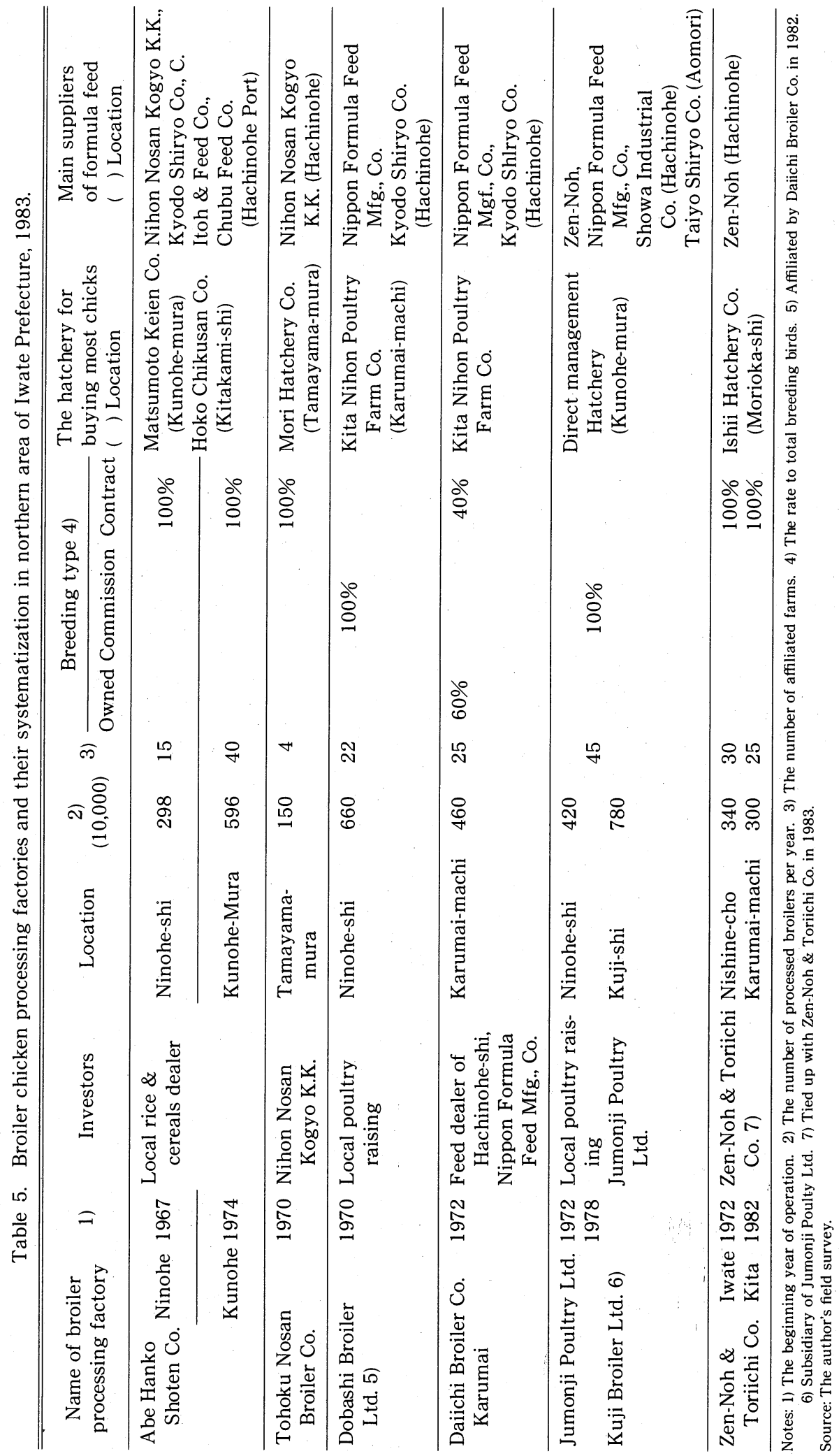


tivation in the said area, bringing about the formation of the production area.

In the case of the Tajima area, where the processing factories were concentrated in a specific area, severe competition among the factories prevailed to obtain broiler chicken farmers, and produced favorable conditions in the farmer's contract. As for Iwate, the factories started with the committed production system, which enabled a number of capital-poor farms to enter the broiler chicken raising business without dependence on outside financing. On the contrary, convinced of its advantage over other agricultural sectors, the applicants for broiler chicken raising business participation in Miyazaki took an aggressive stance and depended on big loans through the National Loan Facilitation System, for example. Accordingly, they intended to expand their scale of broiler chicken raising for repayment of the loans as well as to encourage successors. In the case of the Fuji area, the processing factory arranged the purchase price of the live birds in advance with the chicken farmer, and paid a compensatory fee calculated by subtraction of the expenses on feed, chicks, chemicals etc. from the predetermined purchase price. Since this method was based on the market price of broiler chickens, it was not always favorable to the producers. With no other processing factories located in the region, the factory could methodically gain contracts favorable to itself.

To conclude, the processing factory may have attempted to incorporate the optimum conditions for gaining profit into the contract system in due consideration of: (1) the regional, agricultural circumstances, including the level of agricultural income, the productivity of land and labor and the farm's ability for new investment; and (2) the competitive conditions of other processing factories.

Integrators' own farms were opened in the four areas, farms which functioned to support the unstable processing volume due to fluctuation in the contract numbers. Actually, the integrators gradually have shifted towards hiring contracted farmers to provide management functions after their own farms opened in rural areas. On the other hand, in production areas neighboring metropolitan areas, they are utilizing broiler chicken farms belonging to contracted farmers who have discontinued broiler chicken raising as direct farms through purchasing.

\section{Management and the location of the broiler raising farms}

The comparative investigation on the management and the location of the broiler raising farms in the four areas has revealed the following five regional differences of the formation of production areas.

(1) Progressive farmers promoted the introduction of broiler chicken raising into both the Tajima and Koyu areas. In the former case, the opportunity of its introduction was brought forth by setting-up of the livestock association as well as on the advice of a local representative. In the case of the northern area of Iwate, the poultry raisers were diversifying agricultural products and the local wholesalers were asking for promising new industries.

(2) In the Fuji and Koyu areas, both the postwar reclaimed lands-land of volcanic ash (the former) and diluvial upland (the latter), broiler chicken raising was introduced to compensate for the poor land conditions. And in the Tajima area and the northern area of Iwate, it was adopted as a measure to diversify from the difficult mountainous agriculture. While the broiler chicken raising farms shifted from poultry managment in the Fuji area, a region of poultry raising, the Tajima area could be termed a self-developed region to which broiler chicken farming was an entirely new type of agriculture. Koyu and the northern area of Iwate, newly-emerging production areas, could acquire broiler chicken raising farm management and raising technique from the advanced production areas.

(3) In the areas except Tajima, farm management has been dependent on blood ties and regional relationships. Consequently, the farmers tend to be located in specific villages. It can be also observed that they have participated in poultry farming over a relatively similar period. The farmers in the Fuji area in particular organized a small group, through which they cooperated in purchasing chicks and feed and in transactions of selling live birds ac- 
cording to the market price method. Thus, contrary to other areas, the contract system did not become prevalent in the Fuji area. Besides, the broiler chicken raising farms in the Tajima and Fuji areas participated in livestock breeding in the past, reflecting a regional character oriented to the livestock industry. The prevalent dislike of slaughtering animals in the Tajima area seems to be an inherent regional characteristic.

(4) In Tajima, Koyu and the northern area of Iwate, where people were more dependent on seasonal migration, the processing factories lured farmers to participate in the broiler chicken industry by offering conditions that would assure them of an income of a certain level throughout the year. Consequently, many farms joined. In the Fuji area, on the other hand, with the varied local employment opportunities such as manufacturing, livestock and tea farming, the broiler chicken industry was unable to offer favorable business conditions, limiting the diffusion of this activity in the area.

(5) In the early stage of this industry in the Tajima and Fuji areas, farms employed two types of broiler chicken sheds i.e. battery and cage feeding. However, these sheds had to be transformed into floor feeding windowless ones from the 1970's as measures to prevent animal waste pollution and to expand the scale of operation. This situation forced a number of farms to withdraw from this activity because of their inability to generate capital for new investment on one hand and anxiety about future financial security on the other.
In Koyu and the northern area of Iwate, farmers were late-starters but held a high passion for broiler chicken raising from the beginning. Since they started with floor feeding houses equipped with more substantial facilities than those in the metropolitan regions, each farmer could assume responsibility for a greater number of broilers.

Reflecting these historically distinctive circumstances, the successors in the advanced production areas have tended to discontinue attending to crop farming, with many farm households carrying out either specialized broiler chicken management or using broiler chicken management as its principal source of income with labor supplied by the aged householders and their wives. On the other hand, with the successors assured, the broiler raising farms in the newly-risen production areas in a large part have been conducting specializing and enterprizing management.

A comparative investigation on the use of the broiler chicken shed will be shown next (Table 6). It is particularly noticed that the open-type broiler chicken sheds are popular at Ninohe City ${ }^{5}$. The open-type predominates at Takanabe Town as well ${ }^{6)}$. But the windowless sheds have almost completely spread over the advanced production areas. The windowless house, much expensive than that of the opentype, is characterized by a much higher chick density per tsubo $\left(3.3 \mathrm{~m}^{2}\right)$ because of its high raising efficiency and labor productivity. An exception is the open-type shed applied in Ninohe City that holds a higher chick density than the Japanese average. This fact may

Table 6. Regional characteristics in the use of broiler chicken sheds, 1985.

\begin{tabular}{|c|c|c|c|c|c|}
\hline \multirow{2}{*}{ Area } & \multicolumn{2}{|c|}{$\begin{array}{l}\text { The number of raised } \\
\text { broilers per } 3.3 \mathrm{~m}^{2}\end{array}$} & \multirow{2}{*}{$\begin{array}{l}\text { Raising term } \\
\text { (day) }\end{array}$} & \multirow{2}{*}{$\begin{array}{l}\text { The number of } \\
\text { chick raising } \\
\text { cycles per year }\end{array}$} & \multirow{2}{*}{$\begin{array}{l}\text { The average } \\
\text { number of } \\
\text { broilers raised } \\
\text { per farm }(1,000)\end{array}$} \\
\hline & $\begin{array}{l}\text { Windowless } \\
\text { type houses }\end{array}$ & $\begin{array}{l}\text { Open-type } \\
\text { houses }\end{array}$ & & & \\
\hline Hidaka-cho & 70 birds & - & 81 & 4.5 & 24.0 \\
\hline Fujinomiya-shi & 64 birds & - & 85 & 4.3 & 14.8 \\
\hline Ninohe-shi & 65 birds & 46 birds & 78 & 4.6 & 42.5 \\
\hline Takanabe-cho & - & 42 birds & 83 & 4.4 & 30.8 \\
\hline The national average 1 ) & \multicolumn{2}{|c|}{42 birds } & 72 & 5.1 & 10.6 \\
\hline
\end{tabular}

Note: 1) Data taken by Central Society of Zootechnical Science (1987).

Source: The author's field survey. 
suggest that managerial variables can bring about better results than those originally anticipated.

\section{Regional structure of the broiler inte- grated system}

As the requirement for the production area formation in the broiler chicken industry of Japan, the following regional conditions have been generally proposed.

(1) The processing factory is located in the vicinity of a feed plant. (2) The large hatchery and the large-scale broiler chicken raising farm households exist in the surrounding area. (3) The region is appropriate to obtain operators in the processing factory at low wages as well as to raise broiler chickens at a low production cost. (4) And the region is favored with good traffic conditions for mass transportation to large distribution centers.

Accordingly, in this section comparative examination of the conditions realized in the said production areas will be done.

In the first place, the regional correlation in the feed supply is examined. Since these study areas (except Tajima) had no substantial ports in their prefectures, the supply of feed was largely dependent on the feed bases in other prefectures. However, in Iwate, inexpensive feed has begun to be supplied systematically after a new feed base was put into operation at Hachinohe New Port, promoting development of the broiler chicken industry, and enabling northern Iwate to emerge as a main production area. A similar development could be observed in Miyazaki, with the feed bases opened at Kagoshima Port and Shibushi Port.

Secondly, the production areas are compared regarding the feed transporting distance. In the northern area of Iwate, 100 to $120 \mathrm{~km}$ away from both Ishinomaki Port and Shiogama Port, the feed transporting distance has been shortened to $40 \mathrm{~km}$ by way of Tohoku Express way since the opening of feed plants at Hachinohe New Port.

The Tajima area is located at a distance of 70 to $90 \mathrm{~km}$ from Kobe Port and Himeji Port. The Fuji area is $120 \mathrm{~km}$ away from Yokohama Port from which the feed is being supplied. But the actual transport time is less than 2 hours by highway. A nearly identical transport time is available in the Tajima area.

On the other hand, two cases can be observed in the Koyu area. The farm households associated with agricultural cooperatives obtain their feed from Hyuga Port that exists about 30 $\mathrm{km}$ away from the Koyu area. But many farms affiliated with business firms obtain their feed from either Shibushi Port or Kagoshima Port that are 100 to $120 \mathrm{~km}$ away from the district.

Usually the freight cost is determined by the means of transport, distance, and volume. But the freight from Hachinohe New Port to northern Iwate is exceptionally high. This is because freight involves payment both for using the port and payment to old plants. However, the present price is 3 yen lower per $\mathrm{kg}$ than charged previously from the feed bases in Miyagi Prefecture.

As for supply of chicks, one may not observe any regional difference among the districts, because it is available in a circle with the radius of $30 \mathrm{~km}$ centering on the processing factory in every area.

Thirdly, the production cost in each area is examined (Table 7). The production cost is the

Table 7. Regional comparison of expenses in broiler production and marketing, 1985.

\begin{tabular}{|c|c|c|c|c|c|c|c|}
\hline Region & $\begin{array}{l}\text { Grower's } \\
\text { price }^{1)} \\
\text { (yen } / \mathrm{kg} \text { ) }\end{array}$ & $\begin{array}{l}\text { Production } \\
\text { costs }^{1)} \\
(\text { yen } / \mathrm{kg})\end{array}$ & $\begin{array}{l}\text { Feed } \\
\text { cost }^{1)}\end{array}$ & $\begin{array}{c}\text { Chick } \\
\text { cost }^{1)} \\
\text { (yen/kg) }\end{array}$ & $\begin{array}{l}\text { Labor } \\
\text { cost }^{1)}\end{array}$ & $\begin{array}{l}\text { Traffic cost } \\
\text { of formula } \\
\text { feed (yen/kg) }\end{array}$ & $\begin{array}{l}\text { Traffic cost of processed } \\
\text { broilers (the greatest } \\
\text { market \& minimum } \\
\text { hours) (yen } / \mathrm{kg} \text { ) }\end{array}$ \\
\hline Tajima & 265 & 255 & 184 & 38 & 28 & 2.5 & 13 (Osaka, 3 h) \\
\hline Fuji & 258 & 258 & 174 & 37 & 34 & 3.33 & 10 (Tokyo, $2.5 \mathrm{~h}$ ) \\
\hline Northern of Iwate & 251 & 242 & 180 & 40 & 19 & 5.0 & 12 (Tokyo, $8 \mathrm{~h}$ ) \\
\hline Koyu & 239 & 233 & 163 & 39 & 24 & 5.0 & 22 (Tokyo, $25 \mathrm{~h}$ ) \\
\hline
\end{tabular}

Note: 1) price or cost per $1 \mathrm{~kg}$ (live bird).

Source: The author's field survey. 
lowest in the Koyu area, followed by that in northern area of Iwate. In the advanced production areas, on the contrary, the elevated labor expense as well as the high land price cause the production cost to rise, a situation which is directly reflected on the producer's price. The feed cost, which occupies the largest part in the production cost, is observed to be higher in the coldest district, reflecting the increased feed consumption by the chickens in the winter season. In addition, the extra cost including electric expenses has to be added to the production cost in the case of a warm district where operation of the ventilating fans in the broiler house is indespensable to prevent underdeveloped chickens due to high temperature and humidity in summer. The expenses for heating in winter also have to be added to the production cost in the cold production area.

The broiler chicken marketing destinations of the four areas are surveyed. The Tajima area is located closest to metropolitan markets, but the unit freight is not lowest among four regions because of the regional character of Osaka market. The reasons for this are as follows: (1) primarily, the local distributing organizations are so intricate, (2) cooperative stores, public markets, wholesalers and retail stores-all these hold a stronger control over the distributing network than the supermarkets do historically. Consequently, the broiler chicken price in this market is higher by 10 to 20 yen per $\mathrm{kg}$ than those in other districts.

On the other hand, the processing factories in both Fuji and Iwate areas control the wholesale sectors, thereby reducing freight costs. In the Fuji area, as a measure to compete with the southern Kyushu production areas in Tokyo market, the processing factories have largely shifted the shipment destinations of the products in the form of cut-up meat to other markets in the Kanto provinces. The Iwate production area has been distributing to its chain stores to establish a trading relationship with the local markets. The Koyu area holds its markets in the three biggest metropolitan regions (Tokyo, Osaka and Nagoya). The traders of this district have organized a mass distribution system that connects with the mass selling stores in these big markets with their products successfully competing with those from the Kagoshima production area.

Finally, let us consider the comparative wage levels in the processing factories among the areas. The cutting-up operation has depended on inexpensive labor in every area, which have been done mainly by women employed on a part-time basis. The wage level is determined by similar local factories in the same area. However, pay is raised when employees are scarce. The Tajima area is a low income region in Hyogo. Nevertheless workers are paid relatively high by-the-hour wages because of the local aversion toward butchering. In the Fuji area, where the processing factory used to produce mainly whole chicken and occasionally cut-up meat (due to its labor consuming process), the processing factory has begun to carry out the latter process more often now in order to meet the demand for processed meat in markets. However, with Gakunan industrial area, the factory is in a situation where it is difficult to employ workers. Accordingly, the segmenting system has been applied: processing the whole body at Fujinomiya City and cutting-up the meat at Shimizu City.

On the other hand, due to the scarcity of off-farm employment opportunities in both Iwate and Miyazaki, the processing factories in these areas have been functioning by offering working places for the people on the farm. Thus, they have been able to recruit a stable work force by paying only relatively low wages.

For example, the hourly wage of a woman worker in 1968 in each area were 90 yen in the Tajima, 85 yen in the Fuji, 65 yen in Iwate and 60 yen in Miyazaki prefecture ${ }^{7}$. The hourly wage was raised in 1985 to 480 yen, 475 yen, 440 yen and 415 yen respectively. In both years, the wage was lower in the rural areas. It may be understood that the ratio of the labor cost in the total production cost has been lower in the rural areas. It may also be understood that this low wage may have resulted in the rural areas maintaining a leading position in the production of broiler chickens.

\section{Regionality of the broiler industry}

The findings on the regional characteristics 


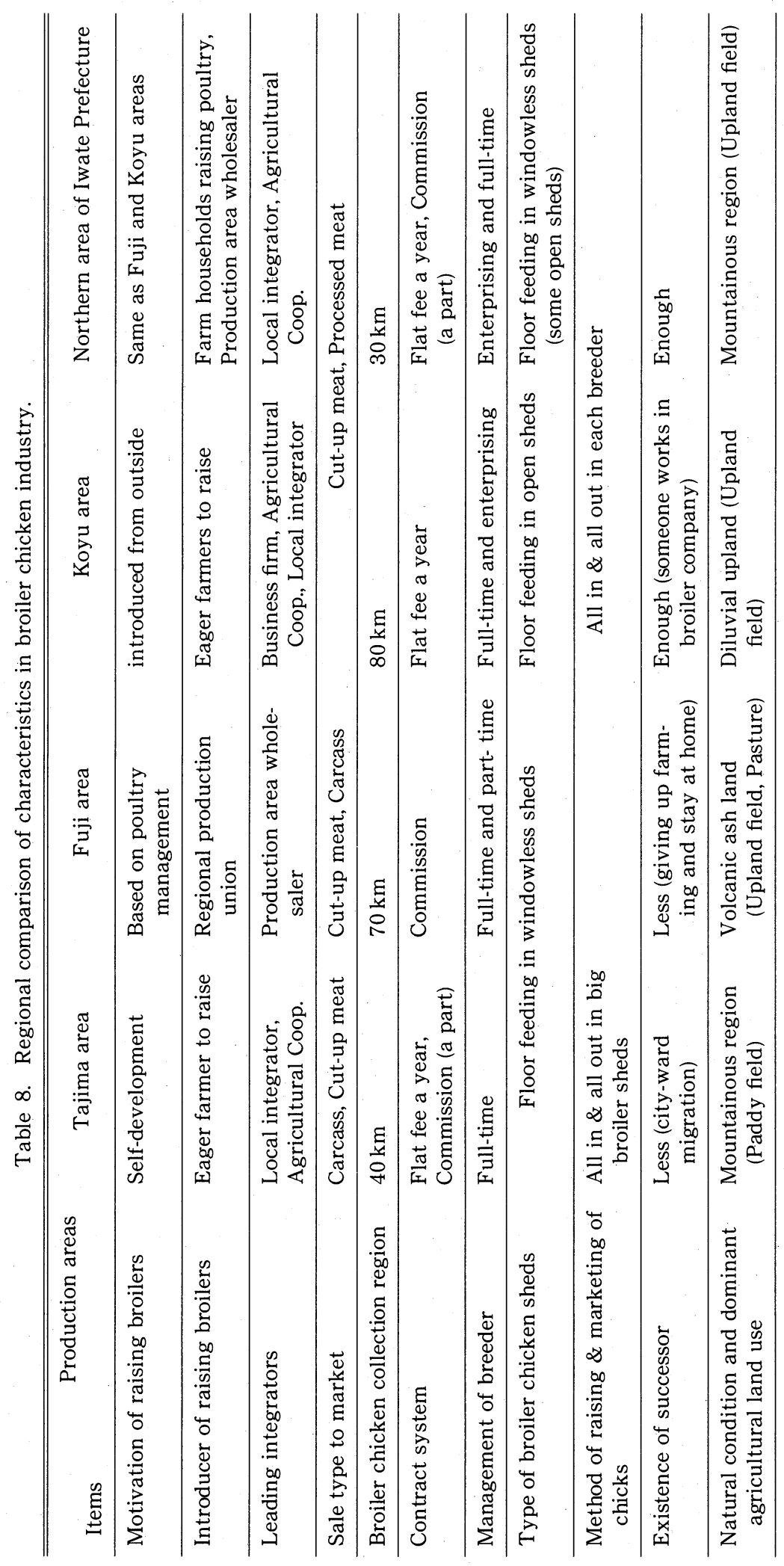


in the four broiler chicken production areas are listed in Table 8.

The production areas in the broiler industry can be roughly classified into the two types: the metropolitan type and the remote type.

Accordingly, the Tajima and Fuji areas represent the former, and Koyu and the northern area of Iwate belong to the latter. The broiler chicken industry of the metropolitan type has progressed through shipment of the body to supply fresh broiler chickens to neighboring markets. However, management specializing in broiler chicken production is generally conducted with family labor chiefly contributed by the aged members, because most successors have given up agriculture. Further, owing to the problem of animal waste pollution and from the standpoint of the broiler raising environment, farmers had to removed the chicken sheds into those of the windowless type during the mid 1970's. In those days with the successors becoming fewer and with facility investment depressed, a number of farms demolished their chicken sheds and returned to crop cultivation, or otherwise shifted to non-agricultural occupations. This situation drove the integrators to curtail their scale of management. They have been attempting a continuation of the broiler business ever since. Actually, they are promoting rationalizations in the producing, processing and distributing sectors, aiming to form production areas that may not be directly competitive with those in the remote areas.

Concerning the production areas of the rural type, multiple integrators advanced into areas with fragile agricultural bases. They distributed the hatcheries and breeding farms that belonged to their groups, affiliated farm households, and constructed their own farms. With the transportation system innovated by diffusion of refrigerating facilities, and with the consuming trend shifting since the beginning of the 1970's, they came to organize regional systems that combined the production area directly with the supermarkets in the big consuming areas to sell the cut-up meat in large volume. In addition, the local government as well as agricultural cooperatives stressed promotion of the livestock industry, bringing feed bases to be constructed in the surrounding regions, a condition that enlarged the territory for securing the broiler raising farms. Since the rural area is not well suited to cereal crops, younger generations have not been pursuing this livelihood. However, by virtue of introducing chicken raising, they can now anticipate stabilized farm management as well as a stable income. Some chicken farms, one may observe, have carried out enterprising management that not merely incorporates securing employees but also encourages possible successors.

Another characteristic concerning the function of the integrators in the new production areas is that they have attempted to form effective organization in investment, technology and production. They have always considered the general economic and social conditions, and, moreover, have taken over the features of the broiler industry in the advanced production areas through optimalizing the conditions of the regional chicken farming industries according to the location and the agricultural management characteristic of their areas.

The general conditions were found as to the formation of the production area in the broiler industry in both the regions adjacent to metropolitan areas and those of the remote area. They are as follows.

Firstly, business firms and agricultural cooperatives participated in the broiler chicken industry by setting up plural processing factories through which they started competition to secure cooperation of chicken raising farm households. Consequently, with the production area expanding spatially, the respective farms gradually enlarged their production scale to carry out specialized broiler management and make it their principal source of income.

Secondly, the integrators advanced into the mountainous areas, where many households were cultivating small size farms in inferior land conditions. These farms accordingly built facilities which were applied to livestock farming and no longer depended on the land fertility, while expecting larger and more stable incomes than previously.

Thirdly, in the areas with no major industries, the number of the farms that introduced chicken farming increased for the following reasons: (1) chicken farming requires a rela- 
tively small investment, (2) it is manageable for an unexperienced farm household and (3) it assures these households of a relatively higher income.

Fourthly, the factors affecting the development and the continuation of broiler chicken industry in the production areas of various types may be classified into four categories: (1) transition of the competitive environment, such as the urbanization and industrialization of the area, (2) traffic conditions, including progress in the means of transport, (3) changes in economic condition, such as a shift of the demand for products and of the distribution route, and (4) technological developments, including improvement of the broiler house and its facility and system reformation in chick arrival and broiler chicken shipment.

At the same time, the regionally inherent conditions were considered to exert a remarkable influence on the formation of the production area. They include: (1) natural conditions, such as climate and soil fertility, (2) managerial conditions of the farm household, such as of arable land, content of crop cultivation, labor force and its financial state, (3) socio-cultural conditions, such as local custom, response of local inhabitants and leadership.

\section{CONCLUDING REMARKS}

As a concluding remark, a brief comment is given on the production areas of the Japanese broiler chicken industry which is concentrated in the rural areas. Integrators have attempted to construct an integrated system or a regional organization to connect the production area directly with the market as well as to reduce production costs. Accordingly, the broiler industry is susceptible to the non-agricultural economic factors, the variables that include the product price fluctuation mainly attributable to that of the imported feed and the profit ratio in distribution sectors. Further, the broiler industry tends to compress the production cost, thus favoring only the district in which inexpensive land and labor are available.

In the broiler chicken industry one may observe that the producing segments such as the processing factory, the hatchery, the formula feed agent and the raising farm are located in a certain broiler chicken collection region. They reinforce mutual relationships to strengthen their management; arranging the producing groups in the vicinity of the feed base, locating the processing factories at the center of the production area, and concentrating the producing organizations near its surroundings to aspire both to their specialization and scale enlargement.

Moreover, the agri-businesses affiliated with huge business firms with full use of modern technology advanced into the broiler chicken industry. This was a move that promoted reformation in the characteristics of the farm households and the structure of the regional agriculture from outside of the district. However, the regionally inherent characteristics, such as the land condition, the specific agricultural operation and the farmer's character, have been strongly reflected in the history of the main production area formation.

To summarize, it is clear that areas which have had the least experience so far may become technologically most advanced and biggest production areas, utilizing their regional characteristics in forming an agricultural production area.

\section{Acknowledgements}

This paper is based largely on a dissertation submitted to the University of Tsukuba for a Ph. D in Science in 1990.

In the course of this study, the author gained much from a number of scholars to whom he owes tremendous thanks. Particularly Professor Shozo YAMАмото of the University of Tsukuba has given to the author continuous encouragement and earnest advice. And Dr. Nobuo Takahashi and Dr. Isao Saito of the University of Tsukuba were kind enough to guide the author in the design of this study. Moreover, Professor Takashi Okuno, Professor Hiroshi SASAKI and other scholars in Institute of Geoscience of the University of Tsukuba supported the author during the course of this research.

Further, the author is deeply grateful to professor Mineaki KanNo of Saitama University and Associate Professor Richard H. SchAEPE of Osaka ElectroCommunication University for their critical reading and revision on this manuscript, and to Professor Tadahito KAwAI of Kinki University for his help in English translation of the study. 
(Received Jun. 1, 1990)

(Accepted Apr. 3, 1991)

\section{Notes}

1) According to the regionalization by Ministry of Agriculture, Forestry and Fishery and that by the Economic Planning Agency, the following areas were divided. In the environs of the metropolitan regions (the areas existing within 150 $\mathrm{km}$ from the major metropolitan areas) 23 prefectures are located (along the Pacific Ocean): These are Tokyo, Osaka, Aichi, Ibaraki, Tochigi, Gunma, Saitama, Chiba, Kanagawa, Shizuoka, Yamanashi, Gifu, Mie, Shiga, Kyoto, Hyogo, Nara, Wakayama, Okayama, Hiroshima, Yamaguchi, Fukuoka and Oita. In the intermediate areas (within 150 to $300 \mathrm{~km}$ from the said areas), there are 14 prefectures. These are Miyagi, Yamagata, Fukushima, Nigata, Toyama, Ishikawa, Fukui, Nagano, Tottori, Shimane, Tokushima, Kagawa, Ehime and Kochi. In the remote areas (beyond $300 \mathrm{~km}$ ), Hokkaido and other 9 prefectures are located.

2) This concept is an application of the "milkshed" defined by Fielding (1964), Durand (1964) and SAITo (1968) to express a functional region in which a milk plant collects fresh milk. In addition, the broiler chicken raising farms are likely to be located close to both the hatchery and the processing factory to shorten the transporting time of chicks and to prevent weight loss of live birds through rapid treatment after collection. On the other hand, however, a minimum separation of 500 meters between the chicken farms is hopefully required to prevent infectious diseases, and simultaneous practice of chick arrival and chicken shipment is also needed.

3) Mitsui \& Co., Ltd., Mitsubishi Corporation, Sumitomo Corporation, Marubeni Co., Ltd., C. Itoh \& Co., Ltd., Toyo Menka Kaisha, Ltd., Nichimen Corporation, Nissho Iwai Corporation, Kanematsu-Gosho Ltd., Toshoku Ltd., and Ataka Industry Corporation (went bankrupt in 1977).

4) The chicken price is determined by subtracting the processing cost and the freight cost, about 15 yen in total, from the receipt price for carcass of 1 $\mathrm{kg}$ at the processing factory. In the case of the guaranteed payment system, the minimum transaction price is predetermined. When the market price drops below this, the difference is supplemented from reverse funding. In the reverse case, 10 yen is subtracted from the predetermined price. This system is not profitable for the farms, unless the market price soars. The flatfee-a-year system seems to be most stable. The market price method holds a risky aspect because of instability of the poultry market.

5) In Iwate Prefecture, all the farm households affiliated by Jumonji Poultry and Dobashi Broiler and a part of those incorporated to Abe Hanko Shoten are using open-type chicken sheds in which a heat supplying system is used in winter with the side windows closed, thus lifting the broiler production cost per $1 \mathrm{~kg}$ by about 10 yen compared with that in the case of the windowless house. (Interview at some of the processing factories concerned.)

6) The windowless house can be found only in the direct farm owned by a business firm.

7) The figure of 1968 was obtained at the oldest factory in each area and that of 1985 was at the factory with the largest scale in the area relatively.

\section{References}

Durand, L. (1964): The major milksheds of the northeastern quarter of the United States. Econ. Geogr., 40-1, 9-33.

Fielding, G. J. (1964): The Los Angels milkshed: A study of the political factor in agriculture. Geogr. Rev., 54-1, 1-12.

Kitamura, S. (1986a): The regional structure and locational conditions of poultry of Takahama City in Aichi Prefecture. Annals of the Japan Association of Economic Geographers. 32-1, 56-68. (JE)

KiTAMURA, S. (1986b): The regional structure of layer farming in Aichi Prefecture. The Journal of the Faculty of Literature (History), Nagoya University, 32, 215-236. (J)

KitAmuRA, S. (1987): The regional structure of layer farming in Japan, The Journal of the Faculty of Literature (History). Nagoya University, 32, 215236. (J)

Midoro, T., S. Hosoda, F. Suzuki, M. Hirai, S. Kobayashi, K. Kamimura, and H. Komai, (1963): The development of chicken egg market and the progress of leading poultry production areas. Research Series of Rural Economics, 3, 1-122. (J)

Nagasaka, M. (1983): Formation of the broiler industry production area in the southern Kyushu-a case study of Miyazaki Prefecture. Chiri (Geography), 28-5, 61-71. (J)

Nagasaka, M. (1988): The development and formation of the broiler industry production area in Iwate Prefecture. Geographical Review of Japan, 61, 239257. (JE)

NAGAsakA, M. (1989): The development and the characteristics of the broiler industry in the Tajima district of Hyogo Prefecture. The Research Bulletin of the Faculty of General Education, Kinki University, 20-3, 67-85. (J)

Nagashima, H. (1969): The development and the patterns of enterprise of poultry raising in postwar Japan-the case of Kanto district. Geographical Review of Japan, 42, 60-75. (JE)

SAITO, I. (1968): Forming process of dairy region in 
the southeastern Gunma Prefecture. Geographical Review of Japan, 41, 623-640. (JE)

TAKENAKA, K. (1963): Geographical distribution and economical structure of broiler poultry farming. Journal of Rural Community Studies, 18, 65-80. (J)
Usui, S. and Yoshida, T. (1965): Contract breeding of broiler-the actual analysis of Kanto and Kansai districts. Nippon no nogyo (Agriculture of Japan), 42, p. $70,80-83$. (J)

\title{
日本におけるブロイラー産業の産地形成
}

\author{
長 坂 政 信*
}

本論は日本におけるブロイラー産業の産地形成過程を 考察し, 産地形成の地域的条件を明らかにすると共に, それに基づいてブロイラー産業の産地形成の一般的条件 を明らかにすることを研究課題とする。

本研究の事例調查地域として, 先進的産地である大都 市圏周辺地域からは, 西日本でブロイラー産業が最初に 成立し, 現在も大都市圈周辺地域の中で最大の産地であ る兵庫県但馬地方と, 東日本の大都市圈周辺地域で最大 の産地である静岡県富士地方とを取り上げた。遠隔地域 からは, 日本のブロイラー産業の主産地を形成している 宮崎県児湯地方と岩手県北地方を選定した。

その結果, ブロイラー産業の産地形成において, 次の 一般的条件が明らかになった。第 1 に, 総合商社などの
農外資本と系統農協がブロイラー産業に参入し, 複数の 処理場の立地によって契約飼育農家の獲得競争を行っ た。この結果, 飼育農家が空間的拡大を遂げつつ, 次第 に主業化・専業化するための規模拡大が図られてきたこ と。第 2 に, インテグレーターがブロイラー産業に進出 した地域は, 土地条件の悪い山間地や丘陵地で, 1 ha 未 満の零細農家が多く存在していた。このため,これらの 農家では地味に左右されず, 高収益と経営の安定が期待 できる農業として, 施設型畜産を取り入れようとしたこ と。第 3 に, 素人でも経営し易く, 設備投資額が相対的 に少なくて斉むブロイラー経営が最む高所得が得られた ことから，これを取り入れる農家が増大したこと。 